\title{
Low-molecular-weight Dextran in Acute Myocardial Infarction
}

\author{
CHRISTIAN F. BORCHGREVINK,* M.D. ; ERIK ENGER,* M.D.
}

Brit. med. F., 1966, 2, 1235-1238

In spite of vasopressor agents, anti-arrhythmic drugs, early ambulation, and anticoagulant therapy the mortality among patients with acute myocardial infarction is almost $40 \%$. Intensive-care units may reduce this figure, but other attempts to lower the mortality should be sought. Langsjoen et al. (1963) reported the beneficial effect of low-molecular-weight dextran (mean molecular weight 40,000) in acute infarction, the mortality being reduced from 46.6 to $17.6 \%$. Two years later Langsioen (1965) confirmed his favourable impression of this treatment. Lindén (1964) reported a reduction of the mortality from 33 to $15 \%$ in a small series of patients with myocardial infarction receiving low-molecular-weight dextran. Both these studies were, however, carried out without proper controls and therefore do not admit of definite conclusions.

Theoretically, low-molecuiar-weight dextran has many advantages. It has antithrombotic properties (Bryant et al., 1963); it increases plasma volume (Gelin et al., 1961) and may thus prevent shock; it improves blood-flow (Gelin and Thorén, 1961) by reducing viscosity and may therefore improve circulation at the border of the infarction, thereby limiting its extension. It has an antisludging effect (Long et al., 1962), which will improve microcirculation. Sludging of the red cells is a frequent finding in myocardial infarction (Bloch, 1955), and it can itself produce myocardial infarction (Long et al., 1962).

Theoretically, $500 \mathrm{ml}$. of $10 \%$ low-molecular-weight dextran binds $1,000 \mathrm{ml}$. of water. The increase in plasma volume will depend on the injected amount, on the infusion-time, and on the renal function. Dextran molecules of less than 50,00060,000 are cleared by the kidney (Arturson and Wallenius, 1963).

The effect on plasma volume, which may be beneficial by preventing shock, may have an opposite effect on the already strained left ventricle, thus causing pulmonary congestion. On the other hand, Askrog and Fossaberg (1965) used lowmolecular-weight dextran in the treatment of pulmonary oedema, caused by overloading of the circulation, in patients with apparently normal hearts. Severe congestive heart foilure is said by the manufacturer to be a contraindication to lowmolecular-weight dextran therapy.

Weighing the possible advantages against the disadvantages, we believed treatment with low-molecular-weight dextran to be cncouraging enough to warrant clinical trial. With our selection of patients and with the method of administration we have been unable to demonstrate any beneficial effect of low-molecularweight dextran on mortality in patients with acute myocardial infarction.

\section{Material and Methods}

Low-molecular-weight dextran, Rheomacrodex, $10 \%$ in glucose was used. A study was made of patients under 75 years admitted to hospital with symptoms suggestive of acute myocardial infarction of less than 24 hours' duration. The following were excluded: those with diabetes requiring insulin and those with pulmonary oedema or definite signs of pul-

\footnotetext{
- Department VII, Ullevål Hospital, Oslo, Norway.
}

monary congestion, the decision being left to the attending physician.

Myocardial infarction was defined according to the standard rules of this department (Enger et al., 1963), requiring typical E.C.G. pattern with $Q$ waves or ST changes. When the E.C.G. pattern was not obvious the diagnosis was made if three of the following criteria were present: a rise in the sedimentation rate, serum glutamic oxaloacetic transaminase (G.O.T.) valises above 40 units, a typical temperature curve, and a leucocyte count above 9,000 .

The patients admitted to the study were randomized into two groups according to a preconceived list. Separate criteria were made for the two sexes and for the patients with recognized previous infarction.

\section{Treatment}

According to Langsjoen (1963) $1,500 \mathrm{ml}$. of a $10 \%$ solution of low-molecular-weight dextran should be given daily for three days in a continuous drip. We carried out a pilot study with this procedure. Of the 13 patients so treated eight died. In some of these frank pulmonary congestion developed though there had been no previous signs of left ventricular failure. The patients felt uncomfortable with the three-day continuous drip. Rheomacrodex did not influence the clotting or the fibrinolytic mechanism, but the bleeding-time (modified Ivy method) was almost doubled (from 5 to 9.2 minutes) at the end of the three days. As the patients also received anticoagulant therapy, we felt that the effect on the bleeding-time introduced a tendency to bleed of possible clinical importance, since shockthreatened patients can hardly afford even a minor loss. When, therefore, Lindén (1964) reported encouraging results similar to those of Langsioen with a less intensive regime we decided to follow his procedure. Rheomacrodex $500 \mathrm{ml}$. was given intravenously over five hours as soon as possible after admission. This was repeated twice during the first 48 hours. This method did not influence the bleeding-time. If frank clinical signs of pulmonary congestion developed the low-molecular-iveight dextran infusion was discontinued.

Both groups received routine treatment-including vasopressor agents, salt-restriction, digitalis, antiarrhythmic drugswhen required. Anticoagulant therapy, without initial heparin, was given to all patients. In addition one group received Rheomacrodex as described. The study was not double-blind We did not want to infuse the control group with glucose or saline as we were not convinced that this would be completely harmless.

\section{Results}

Of 130 patients who entered the study, 67 received Rheomacrodex and 63 did not. In 28 the original diagnosis of a myocardial infarction could not be confirmed-18 were in the control group and 10 in the treated group. Of the 102 patients with a proved infarction, 57 were treated and 45 were controls (Table I). 
Table II provides information on the comparability of the groups. There were minor differences, but on the whole there is no reason to believe that the groups differed prognostically. About half of the patients in the treated series had the Rheomacrodex infusion started within six hours after the onset of chest pain, and $75 \%$ within 12 hours.

TABLE I.-Survey of the Total Number of Patients

\begin{tabular}{l|c|c} 
& $\begin{array}{c}\text { Treated } \\
\text { Series }\end{array}$ & $\begin{array}{c}\text { Control } \\
\text { Series }\end{array}$ \\
\hline $\begin{array}{l}\text { Total No. of patients } \\
\begin{array}{l}\text { No. with coronary heart disease. } \\
\text { myocardial infartion not verified }\end{array}\end{array}$ Acute & 67 & 63 \\
$\begin{array}{l}\text { No. without signs of coronary heart disease } \\
\text { No. with acute myocardial infarction }\end{array}$ & 8 & 2 \\
remaining for evaluation of therapy & 57 & 15 \\
\hline
\end{tabular}

TABLE II.-Comparison Between the Two Groups on Admission

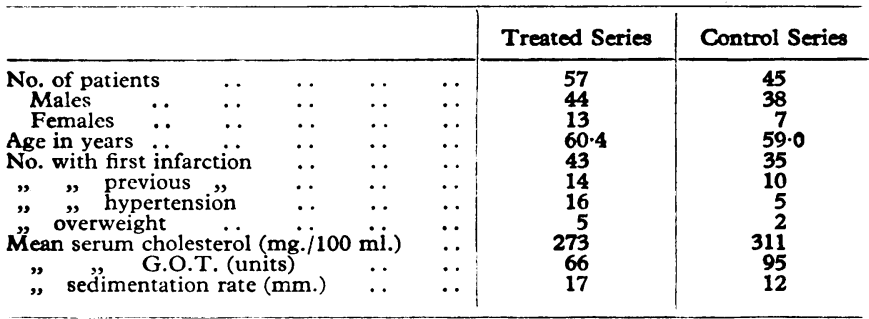

In nine patients the infusion had to be stopped because of clinical signs of increasing pulmonary congestion. Four of these patients died-two on the second day, one on the ninth day, and one on the 25 th day. In three the infusion was not completed because of death on the first day. These patients had each received $500 \mathrm{ml}$. of Rheomacrodex; one of them developed severe pulmonary congestion. The treatment with Rheomacrodex was thus completed in 45 of the 57 patients.

Fig. 1 gives the mean value of serum G.O.T. during the first five days. The initial transaminase value was lower in the

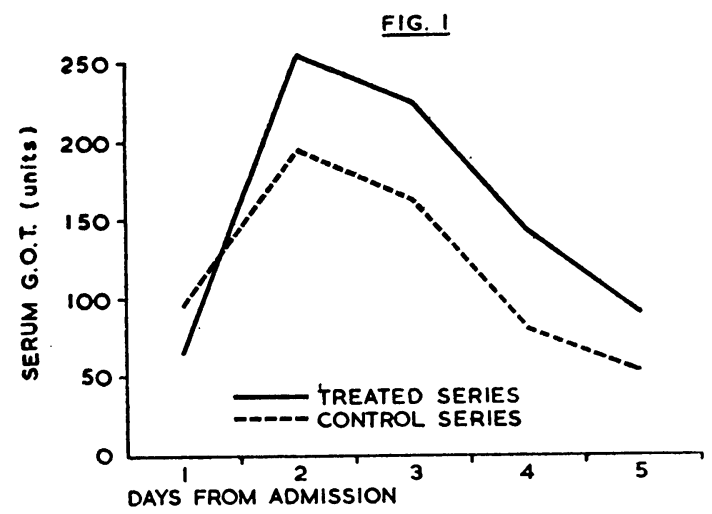

Fig. 1.-Mean serum G.O.T. values in the two series.

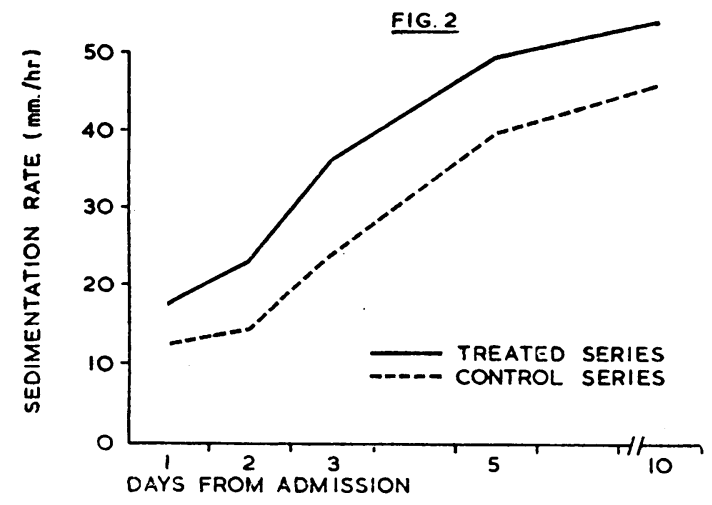

FIG. 2.-Mean sedimentation rate in the two series. treated group, but on the second day it was higher and remained so. The difference between the two groups in respect of the mean increase of serum G.O.T. from the first to the second day is statistically significant $(\mathrm{P}<0.01)$.

Fig. 2 gives the corresponding values for the sedimentation rate during the first 10 days. The small difference on the first day increased slightly during the next day, and the sedimentation rate remained higher in the treated group.

Fig. 3 gives the mean thrombotest curves during the stay in hospital. The intensity of the anticoagulant therapy was satisfactory, and the same in the two groups.

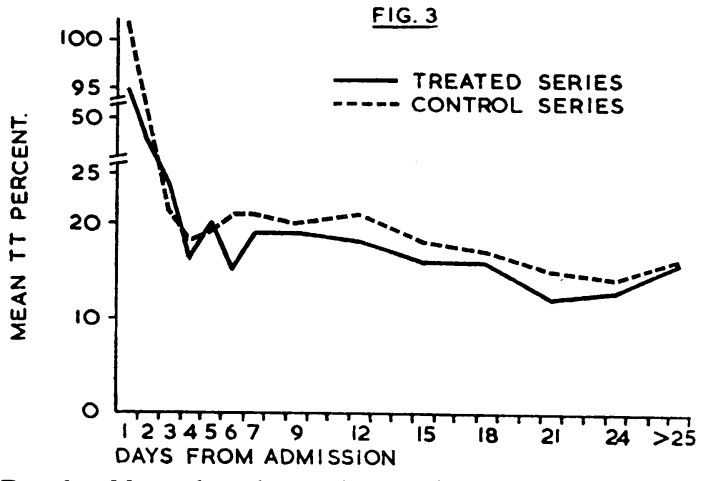

FIg. 3.-Mean thrombotest (TT) values in the two series.

Table III shows pertinent data on the patients during their stay in hospital. Congestive heart failure developed significantly more often in the treated patients than in the controls $(0.01<\mathrm{P}<$ 0.05). Pneumonia, post-infarction syndrome, and arrhythmia were also more frequent in the treated series, though the differences between the groups were not statistically significant. The percentage of patients needing vasopressor agents was the same. There was no thromboembolic complication in either group and only one minor bleeding episode in the control series. The mean duration of the hospital stay was slightly longer in the treated group, mainly because of the patients with post-infarction syndrome.

Table III.-Comparison of Clinical and Biochemical Data in the Two Series of Patients

\begin{tabular}{|c|c|c|}
\hline & Treated Series & Control Series \\
\hline 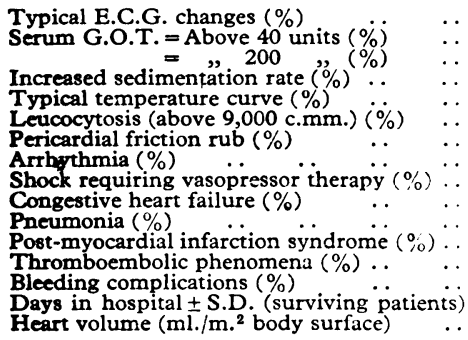 & $\begin{array}{l}88 \\
89 \\
54 \\
91 \\
72 \\
66 \\
18 \\
40 \\
21 \\
58 \\
14 \\
7 \\
0 \\
0 \\
30 \pm 13 \\
460\end{array}$ & $\begin{array}{c}91 \\
93 \\
44 \\
87 \\
76 \\
67 \\
9 \\
27 \\
22 \\
31 \\
2 \\
0 \\
0 \\
2 \\
26 \pm 6 \\
440\end{array}$ \\
\hline
\end{tabular}

$$
\text { * } 0.01<P<0.05 \text {. }
$$

None of the excluded patients died. The results in the 102 patients with proved myocardial infarction are given in Table IV, which shows a higher mortality in the treated seriesnamely, $14 \%$ against $8.9 \%$. The difference is not statistically significant. A detailed description of the fatal cases and the necropsy findings are given in Table V. All 12 patients who died had an acute myocardial infarction.

\begin{tabular}{|c|c|c|c|c|}
\hline & & & Treated Series & Control Series \\
\hline $\begin{array}{l}\text { No. of patients } \\
\text { ", deaths* }\end{array}$ & $\begin{array}{ll} & \\
\cdots & \cdots\end{array}$ & $\cdots$ & $\begin{array}{c}57 \\
8(14 \cdot 0 \%)\end{array}$ & $\begin{array}{c}45 \\
4(8.9 \%)\end{array}$ \\
\hline
\end{tabular}


TABLB V.-Clinical and Necropsy Data on the Patients Who Died

\begin{tabular}{|c|c|c|c|c|c|}
\hline $\begin{array}{l}\text { Sex } \\
\text { and } \\
\text { Age }\end{array}$ & $\begin{array}{l}\text { Time from } \\
\text { Admission } \\
\text { Until } \\
\text { Death } \\
\text { (Days) }\end{array}$ & $\begin{array}{l}\text { Clinical } \\
\text { Cause of } \\
\text { Death }\end{array}$ & $\begin{array}{c}\text { Heart } \\
\text { Weight } \\
\text { (g.) }\end{array}$ & $\begin{array}{c}\text { Necropsy } \\
\text { Findings of } \\
\text { Congestive } \\
\text { Heart } \\
\text { Failure }\end{array}$ & $\begin{array}{l}\text { Other Necropsy } \\
\text { Findings of } \\
\text { Importance }\end{array}$ \\
\hline M 47 & 1 & Shock $\quad$ Treated & $\begin{array}{c}\text { Series } \\
380\end{array}$ & Severe & $\begin{array}{l}\text { Acute myocardial } \\
\text { infarction with } \\
\text { thrombotic cor- } \\
\text { onary occlusion }\end{array}$ \\
\hline M 61 & 12 & Ventricular fibrilla- & 540 & Moderate & " \\
\hline M 43 & 9 & $\begin{array}{l}\text { Congestive heart } \\
\text { failure. }\end{array}$ & 530 & " & , \\
\hline M 70 & 2 & $\begin{array}{l}\text { Ventricular fibrilla- } \\
\text { tion-shock }\end{array}$ & 510 & " & ", \\
\hline $\begin{array}{ll}\mathrm{F} & 65 \\
\mathrm{~F} & 70\end{array}$ & $\begin{array}{r}2 \\
25\end{array}$ & $\begin{array}{l}\text { Shock } \\
\text { Sudden death }\end{array}$ & $\begin{array}{l}230 \\
510\end{array}$ & None & $\begin{array}{l}\text { Acute" and old"myo } \\
\text { cardial infarction } \\
\text { without coronary }\end{array}$ \\
\hline M 66 & 1 & $\begin{array}{l}\text { Congestive heart } \\
\text { failure }\end{array}$ & 490 & Severe & $\begin{array}{l}\text { occlusion } \\
\text { Acute myocardial } \\
\text { infarction with } \\
\text { thrombotic cor- } \\
\text { onary occlusion. } \\
\text { Rupture of myo- } \\
\text { cardium }\end{array}$ \\
\hline M 63 & 1 & Sudden death & 490 & Moderate & 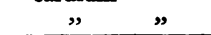 \\
\hline M 73 & 3 & $\begin{array}{c}\text { Control } \\
\text { Congestive heart } \\
\text { failure and shock }\end{array}$ & $\begin{array}{c}\text { Series } \\
450\end{array}$ & Moderate & $\begin{array}{l}\text { Acute myocardial } \\
\text { infarction with } \\
\text { thrombotic cor- }\end{array}$ \\
\hline M 65 & 1 & Sudden death & 300 & Severe & $\begin{array}{l}\text { Rupture of myo- } \\
\text { cardium, acute } \\
\text { myocardial in- } \\
\text { farction, and } \\
\text { thrombotic cor- } \\
\text { onary occlusion }\end{array}$ \\
\hline $\begin{array}{lr}F & 75 \\
M & 55\end{array}$ & 8 & ", & $\begin{array}{l}340 \\
440\end{array}$ & $\begin{array}{l}\text { Moderate } \\
\text { None }\end{array}$ & ", " \\
\hline
\end{tabular}

\section{Discussion}

In the pilot study we followed the procedure of Langsioen, giving continuous infusion of low-molecular-weight dextran, $1,500 \mathrm{ml}$. a day for three days. The patients felt uncomfortable. Since we introduced a tendency to bleed, and as pulmonary congestion developed in some of the patients, we believe that this intensive treatment might be harmful. The simplified procedure of Lindén (1964) had apparently given the same striking result on mortality and was therefore adopted.

A comparison between the two groups with verified infarction showed that they were well matched, though there were more treated patients with hypertension. The course of the disease seemed to differ in the two series, as more treated patients developed congestive heart failure, post-infarction syndrome, arrhythmia, and pneumonia. The latter complication may be a consequence of the pulmonary congestion. The increase in serum G.O.T. value from the first to the second day was significantly greater in the patients receiving Rheomacrodex. This may be due to liver congestion or to more pronounced myocardial necrosis in the treated series. As we have no reason to believe that the groups differed prognostically on admission, the different clinical course suggests that Rheomacrodex had an unfavourable effect. Thus the theoretical advantages were outweighed by an increased stress of low-molecular-weight dextran infusion on the already strained left ventricle.

The number of patients needing vasopressor agents was the same in the two groups, showing that Rheomacrodex apparently did not prevent shock. It is noteworthy that there was no thromboembolic complication in the two groups; this we attribute to the anticoagulant therapy. A thrombotest level of 15 to $20 \%$ seems sufficient to prevent venous thrombosis without undue risk of bleeding.

We were unable to show any beneficial effect of Rheomacrodex on the mortality rate. In fact, the treated patients had a higher mortality than the controls. Thus the results of Langsjoen et al. (1963) and Lindén (1964) are not confirmed. It is remarkable that Langsjoen et al. found a mortality of $17.6 \%$ in their treated patients and Lindén $15 \%$, which are very close to the $14 \%$ mortality in the present series. However, neither Langsjoen et al. nor Lindén had a comparable control group, selected according to proper statistical principles. They therefore compared their results with previous experience in the same hospitals. Langsjoen et al. found a reduction in mortality from 46.6 to $17.6 \%$ and Lindén from 33 to $15 \%$. If we had followed the same principle we would have found a reduction from $40 \%$, which is the average mortality in patients with acute myocardial infarction in this hospital, to $14 \% \mathrm{ir}$ : our treated series. This once again stresses the paramount importance of having a proper control group, as the mortality of $14 \%$ should, of course, not be compared with our previous experience of $40 \%$, but with $8.9 \%$ in the present control group The latter mortality is remarkably low. This is most probably related to our criteria of selection of patients, particularly to the exclusion of those showing obvious clinical signs of pulmonary congestion. The exclusion of old patients and of those dying on admission will further reduce the mortality in the remaining patients. Any comparison with previous experience has little meaning, as it is almost impossible retrospectively to select a comparative "control" group.

From Table I we can calculate that in the patients wirh coronary heart disease a diagnosis of acute myocardial infarction was maintained in $88 \%$ of the treated series against $75 \%$ of the controls. Though this difference is not statisticaliy significant, it may indicate that in patients with impending infarction Rheomacrodex actually enhanced the development of myocardial infarction or at least influenced some of our diagnostic criteria.

Our results should perhaps be compared directly only with those of Lindén (1964), as Langsjoen et al. (1963) used a longer and more intensive treatment. However, our experience in the pilot study, when we copied Langsjoen's procedure, was not encouraging, and we therefore very much doubt that this regimen would have improved the prognosis in the treated series.

Our study was not double-blind, as we did not feel justified in giving placebo infusions with saline or glucose to the control patients. Therefore a bias may have been introduced when evaluating congestive heart failure. The difference in the occurrence of pneumonia, arrhythmia, and post-infarction syndrome can hardly be explained by bias. It seems highly improbable that the mortality figures, which form the basis for rejecting Rheomacrodex treatment in acute myocardial infarction, would have differed if the study had been double-blind Therefore we believe that conclusions of general validity may be drawn from the study.

\section{Summary}

Patients with symptoms suggestive of acute myocardial infarction of less than 24 hours' duration were randomized into two groups according to a preconceived list. Both groups received routine treatment, including anticoagulant therapy. In addition, one group received low-molecular-weight dextran (Rheomacrodex) $500 \mathrm{ml}$. of a $10 \%$ solution three times during the first 48 hours after admission.

Of the 130 patients entering the study 102 had proved myocardial infarction; 57 of these received Rheomacrodex, 45 did not. The groups were well matched.

The increase in mean serum G.O.T. values from the first to the second day was significantly higher in the treated series. Congestive heart failure developed in $58 \%$ of the treated patients and in $31 \%$ of the controls $(0.01<P<0.05)$. Furthermore, pneumonia, arrhythmia, and post-infarction syndrome occurred more frequently in the treated group.

Eight $(14 \%)$ of the treated patients died, against $4(8.9 \%)$ of the controls. The difference is not statistically significant.

It is concluded that low-molecular-weight dextran administered as described does not improve the prognosis in patients with acute myocardial infarction. The results suggest, on the 
contrary, that it may be harmful. This is in contrast to previous studies.

Rheomacrodex was supplied by Pharmacia, Uppsala, Sweden.

\section{REPERENCES}

Arturson, G., and Wallenius, G. (1964). Scand. 7. clin. lab. Invest., 16,81 .

Askrog, V., and Fossaberg, E. (1965). Ugeskr. Lag., 127, 965.

Bloch. E. H. (1955). Amer. F. med. Sci., 229, 280.
Bryant, M. F., Blocm, W. L., and Brewcr. S. S. (1963). Amer. Surg., $29,256$.

Enger, E., Julsrud, A. Chr., and Kirkeby, K. (1963). Acta med. scand., Suppl. No. 397.

Gelin, L. E., Sölvell, L., and Zederfeldt, B. (1961). Acta chir. scand., 122, 309.

and Thorén, O. K. A. (1961). Ibid., 122, 303

Langsjoen, P. H. (1965). Tex. St. F. Med., 61, 92.

Falconer, H. S., Sanchez, S. A., and Lunch, D. i. (1963) Angiology, 14, 465 .

Angiology, 14, 465.
Lindén, L. (1964). Svenska Läk.-Tidn., 61, 2300.

Long, D. M., Myer, M. W., Brown, E. B., and Lillehei, (.. W'. (1962). Amer. F. Cardiol., 10, 695.

\section{Life-table for Cystic Fibrosis}

\section{J. MANTLE, * M.R.C.S., L.R.C.P. ; A. P. NORMAN,* M.A., M.D., F.R.C.P., D.C.H}

Brit. med. 7., 1966, 2, 1238-1241

Life-tables can be of value in assessing the social problem which a disease presents and in evaluating the success of different methods of treatment. Two methods of constructing a lifetable are available if a hospital series is used: (1) entering the patient from the age at proved diagnosis, and (2) entering the patient from birth. The first method will probably overestimate mortality, especially when diagnosis tends to be made shortly before death. The second will probably underestirate mortality, except in surveys of specific geographical areas in which all patients with the disease may be expected to be ascertained.

Cystic fibrosis is the commonest autosomal recessively determined disease of childhood. The best estimate of incidence in children of European stock is probably that of Danks, Allan, and Anderson (1965), which gives an incidence of approximately 1 in 2,400 live births.

\section{Source of Case Material}

A survey has been made of 498 children attending the Hospital for Sick Children between 1943 and midsummer 1964 who were coded in the hospital records as suffering or possibly suffering from cystic fibrosis. One further case was identified from a search of the post-mortem index, giving a total of 499 cases. Of these cases 399 were coded as suffering from cystic fibrosis and 100 from cystic fibrosis presenting with meconium ileus. Below are given the clinical and laboratory data resulting from the invesigation.

\section{Cystic Fibrosis Not Presenting as Meconium Ileus}

Examination of the case material disclosed pronounced variation in both the presence and the degree of characteristic clinical features. The diagnostic laboratory data consist of tests of tryptic activity of the duodenal juice or the sodium content of the sweat. As would be expected for cases collected over a period of more than 20 years, one or both tests had not always been carried out.

The variability both in clinical manifestation and in laboratory data is of potential importance in the construction of a life-table for the disease. Where laboratory data were not available the diagnosis was more likely to be correct in those cases in which the clinical manifestation was typical than in those in which it was not. Assay of the tryptic activity of the duodenal juice is not as reliable a confirmatory test as is the concentration of sodium in the sweat. For these reasons

- M.R.C. Clinical Genetics Research Unit, the Institute of Child Health, and the Hospital for Sick Children, London. the patients were divided into four primary groups, according to the presence or absence of the two laboratory tests and to the results. Each of these groups was then subdivided according to the clinical manifestations.

\section{Classification on Laboratory Test Findings}

Assay of the tryptic activity of the duodenal juice before 1952 was carried out by the method of Andersen and Early (1942). From 1952 until 1962 the method of Horsfield (1952) was used, and subsequently that of McGowan and Wills (1962). Inability to digest gelatin at a titre of $1: 100$ of the juice in the case of the two former methods, and a tryptic activity of the juice of less than 7 units by the latter method, were regarded as confirmatory. In all instances where the $\mathrm{pH}$ of the juice was stated to be below 7, or "acid," the results of the test have been excluded.

Prior to 1959 estimation of the sodium content of the sweat was determined by the method of Shwachman, Higgins, and Dooley, as quoted by Shwachman and Leubner (1955), and subsequently by the method of Gibson and Cooke (1959). By either method a sodium level of $70 \mathrm{mEq} / \mathrm{K}$ or $\mathrm{L}$, or greater, was considered confirmatory.

The results of the pilocarpine iontophoresis method have been accepted only in those instances where the weight of sweat obtained was at least $100 \mathrm{mg}$. McKendrick (1962) discussed the effect of age on the sodium content of the sweat and concluded that, in infancy, levels as low as $50 \mathrm{mEq} / 1$. cifer strong evidence of the disease. In the present series there were seven patients in whom the sodium content of the sweat was found to lie between 50 and $70 \mathrm{mEq} / 1$. Of these, four were below the age of 1 year at the time of estimation, and their diagnosis has therefore been accepted as having been confirmed. Laboratory data obtained from tests done at other hospitals were not used in the classification of cases.

The four primary groups were as follows:

1. Diagnosis first confirmed by the sodium content of the sweat -93 cases. (In 21 the diagnosis was subsequently also confirmed by the tryptic activity of the duodenal juice. In seven cases the tryptic activity of the duodenal juice was non-confirmatory.)

2. Diagnosis first confirmed by the tryptic activity of the duodenal juice-163 cases. (In 39 the diagnosis was subsequently also confirmed by the sodium content of the sweat.)

3. Diagnosis not confirmed by either test, since neither test was done-105 cases.

4. Diagnosis regarded as not confirmed by laboratory tests-27 cases: duodenal juice confirmatory but sweat test non-confirmatory, 2 cases; duodenal juice non-confirmatory, sweat test not done, 17 cases; sweat test non-confirmatory, duodenal juice not examined, 6 